\title{
Migrant Entrepreneurship from the Perspective of Cultural Diversity
}

\author{
Mediha Sahin \\ Department of Spatial Economics, Free University Amsterdam \\ De Boelelaan 1105, 1081 HV Amsterdam, The Netherlands \\ msahin@,feweb.vu.nl
}

\section{Peter Nijkamp}

Department of Spatial Economics, Free University Amsterdam

De Boelelaan 1105, 1081 HV Amsterdam, The Netherlands

pnijkamp@,feweb.vu.nl

\section{Tüzin Baycan-Levent}

Department of Urban and Regional Planning, Istanbul Technical University

Taskisla 34437 Taksim, Istanbul, Turkey

tuzin.baycanlevent@itu.edu.tr

PN222MSTB

\begin{abstract}
$\underline{\text { Abstract }}$
The phenomenon of 'migrant entrepreneurship' refers to business activities undertaken by migrants with a specific socio-cultural and ethnic background or migrant origin. The studies on migrant entrepreneurship in both the US and Europe have recognized the significant share of immigrants in SME activities. In the context of migrant entrepreneurship several scholars have highlighted the impact of different migrant group cultures on entrepreneurship. They emphasize the importance of values like social or business attitude, close family and religious ties and trust, which enable some immigrant groups to compete successfully in business. Against this background, the aim of this paper is to review and evaluate migrant entrepreneurship from the perspective of cultural diversity. The paper investigates key socioeconomic and cultural aspects of migrant entrepreneurship and next addresses different migrant group entrepreneurs in the Netherlands in order to compare the differences between various migrant groups and to explore cultural diversity in migrant entrepreneurship.
\end{abstract}

KEY WORDS: Entrepreneurship, Migrant Entrepreneurship, Cultural Diversity JEL Classification: A13, E24 


\section{MIGRATION IN A MODERN SOCIETY}

Modern cities mirror the openness of an industrialized global society, as they have become a meeting place of people from different national, cultural and migrant origin. In the past decades, most cities in the industrialized world and especially metropolitan areas in many countries have seen a huge influx of people with a different socio-cultural or migrant origin (Cross, 1992; Esping-Andersen, 1993; Massey et al., 1993). In an era of mass migration, migrant workers will be found in many different segments of the labour market, depending on their wage level and professional qualifications. In economic terms, their individual marginal productivity will determine which position they assume on the labour market (Sahin et al., 2006). Since entrepreneurship is one of the frequently used ways to escape unemployment in a host country, it is expected that migrants will attempt to choose self-employment. Entrepreneurship affects the economy both directly and indirectly, and at various levels, through innovation, competition and restructuring (Wennekers et al., 1999). Empirical research has shown that both a higher rate of new business start-ups and a higher rate of turbulence (the sum of start-ups and closures) enhance, after a certain time lag, economic growth and job creation (Carree et al., 2003).

The study of migrant entrepreneurship started preponderantly in the USA (Light, 1972), while later studies on this topic also emerged across Western Europe (Ward and Jenkins, 1984) for the United Kingdom and France (Simon, 1993) and in Israel (Razin, 1993). These studies recognized the significant share of migrants in SME activities. Research on migrant entrpreneurship in Europe, lags behind research in the US (Le, 1999). Recent papers in the rising literature on this issue in Europe and the US, and other immigration countries include Taylor (1996 and 2001), Blanchflower et al. (2004), Verheul et al. (2001), Audretsch (2002), Constant et al. (2003) and Masurel et al. (2005).

Since the early 1980s, self-employment among migrant minorities has increased significantly in Europe and migrant entrepreneurship has become an important topic in the EU, with a great impact on micro, meso and macro levels of development. The booming economy in Europe and the available opportunities in various market niches appear to have led to the emergence of a new breed of migrant entrepreneurs. The migrant minorities in Europe are expected to continue growing and thereby the business ownership among these migrant groups will grow as well. It is generally found that contemporary migrant communities generate entrepreneurs able to contribute more and more to economic growth and the welfare of the host countries (Rettab, 2001). Migrant entrepreneurs make a variety of contributions to the economic environment of their host and home countries. At the microlevel, migrant entrepreneurs help to satisfy a variety of migrant needs and wants for both migrant and non-migrant consumers (Super, 2005). More entrepreneurship is not only desirable and attractive, but also unavoidable. The most important reason is that because of 
globalization and increasing competition there is an enforced tendency towards more flexible job relations in the business.

With the advent of the era of mass migration in Europe, the issue of cultural diversity has gained increasingly societal and political interest, unfortunately often from a negative perspective. It has even become a source of big concern in European societies. Generally speaking, migrant minorities are found to have lower labour force participation rates, lower employment rates, to be less qualified, to accept relatively less skilled jobs, and are particularly specialized in production. The majority of migrant minorities tend to earn relatively less than the population as a whole.

Cultural Diversity is the variety of human cultures in a specific region, or in the world as a whole (Wikipedia, 2006). In the context of migrant entrepreneurship, several scholars have highlighted the impact of different ethnic group cultures on entrepreneurship. They emphasize the importance of values like social or business attitude, close family and religious ties, and trust, which enable some migrant groups to compete successfully in business (Ward, 1983; Werbner, 1990; Waldinger et al., 1990). The literature also points out differences in entrepreneurial abilities; some people are more entrepreneurial than others. There are several reasons - like economic and psychological motives (profit, propensity to take risk, a spirit of adventure, access to information or knowledge and desire to innovate) - why migrants opt for self-employment. The interaction between culture and migrant entrepreneurship is complex (Basu et al., 2002). Cultural and socio-psychological attributes of different migrant groups affect their entrepreneurial behaviour. Ethnic minorities may differ in terms of their reasons for migration, their religion, their language, their educational attainment, their demographic background (whether other relatives are in business or not) and their access to family business networks. Some of these differences reflect cultural diversity among the relevant groups concerned. Culture, in the form of a family tradition in business and strong family ties, has an impact on business entry motives, on the financing of new start-ups and on the nature of business chosen. Some aspects of culture like family tradition seem to have greater impact on entrepreneurship than others like religion (Basu et al., 2002). It is still a source of debate in the literature whether specific forms of a religion do exert an influence on entrepreneurial behaviour. Furthermore, there is some evidence suggests that the interaction between culture and entrepreneurship may change over time, that is between business entry and later business operations.

Against this background, the aim of this paper is to evaluate migrant entrepreneurship from the perspective of cultural diversity. The paper investigates the socio-economic and cultural aspects of migrant entrepreneurship and addresses next different migrant group entrepreneurs in the Netherlands in order to compare the differences between various migrant groups and to explore the cultural diversity in migrant entrepreneurship. The next section 
examines the basic concepts of entrepreneurship and migrant entrepreneurship on the basis of main characteristics and a range of determinants from psychological and sociological to economic and demographic ones and evaluates migrant entrepreneurship from socioeconomic and cultural diversity perspective. Section 3 evaluates the development of migrant entrepreneurship in the Netherlands since the 1960s. The following section, Section 4, addresses four active and dominant migrant groups viz. Turks, Morrocans, Surinamese, and Antilleans in the Netherlands and compares these groups with each other as well as with native Dutch group in terms of their entrepreneurial behaviour and performance. Therefore, the section highlights the socio-economic and cultural differences among these groups. The last section concludes with recommendations for future research in this field.

\section{ENTREPRENEURSHIP AND MIGRANT ENTREPRENEURSHIP: A SOCIO- ECONOMIC AND CULTURAL DIVERSITY PERSPECTIVE}

\subsection{Basic concepts of entrepreneurship and migrant entrepreneurship}

Entrepreneurship is a multidimensional concept, the definition depends largely on the focus of the research undertaken (Verheul et al., 2001). Entrepreneurship or self-employment normally involves setting up a new business or buying an existing business. Some people are more entrepreneurial than others. Entrepreneurship in the classical sense refers to the combining of resources in novel ways so as to create something of value (Aldrich and Waldinger, 1990). Another definition of an entrepreneur is "someone who specializes in taking responsibility for and making judgemental decisions that affect the location, form and the use of goods, resources and institutions" (Hébert et al., 1984). This definition is more from an economic point of view.

In a textbook on economics (Stiglitz et al., 2000), the entrepreneur is defined as a person who creates new businesses, brings new products to market, or develops new processes of production. In literature the following four characteristics and main issues centring on entrepreneurship are also examined (Hébert et al., 1982 and Van Praag 1996): i) The position of the entrepreneur both in the surrounding economic system and within his own corporate organization; ii) The identification of the economic tasks of the entrepreneur; iii) The financial remuneration of the entrepreneur for his risk-taking activities, based on his economic motives; iv) The dynamics in (local and global) markets, seen from the perspective of the entrepreneur.

These four attributes of an entrepreneur show up with varying intensities in the literature on the essence of entrepreneurship. There are scientific contributions on entrepreneurship offered by Cantillon, Say, Marshall, Schumpeter, Knight and Kirzner, respectively. The pioneering study of Cantillon (1931) on the role of entrepreneurship made a 
main distinction between the following economic agents: i) land owners who were financially independent: ii) 'arbitrageurs (entrepreneurs) who were involved in risk taking activities with a view to profit-making, and; iii) 'servants' who were ensured of a fairly stable income by means of a labour contract. In Cantillon's view, the market economy was a 'self-regulating network of reciprocal exchange arrangements' which were able to produce equilibrium prices through free entry and exit of business firms. In Cantillon's perception of entrepreneurship, the mediating role of the economic actor, who needs to anticipate uncertain future events and to see uncertainty as an economic opportunity, is more important than his innovative attitude. The 'survival of the fittest' would be best guaranteed by those entrepreneurs who know how to handle risk situations properly.

Different determinants of entrepreneurship, which combine various factors into an eclectic framework, have been defined by Verheul et al. (2001): i) Psychological determinants; focus on motives and character traits; ii) Sociological determinants; focus on the collective background of entrepreneurs; iii) Economic determinants; focus on the impact of the economic climate and technological development; iv) Demographic determinants; focus on the impact of demographic composition on entrepreneurship.

In the literature we observe also a broader treatment of business activities by migrant people. In recent years we have observed a significant shift in the orientation of migrant groups, namely towards self-employment (Baycan-Levent et al., 2003). This movement is generally referred to as migrant entrepreneurship (Van Delft et al., 2000, Masurel et al., 2002, Waldinger et al. 1990, Ward et al., 1984). The latter phenomenon distinguishes itself from 'normal' entrepreneurship through its orientation on migrant products, on migrant market customers or on indigenous migrant business strategies (Choenni, 1997). Migrant entrepreneurship is also generally regarded as an important self-organizing principle through which migrant minorities are able to improve their weak socio-economic position (BaycanLevent et al., 2003). There is a significant difference among various migrant groups.

Chaganti et al., (2000) make the following distinction into three groups of migrant businessmen: i) Immigrant entrepreneurs; immigrant entrepreneurs are individuals who, as recent arrivals in the country, have had to start a business as a means of economic survival (Butler et al., 1997); ii) Migrant entrepreneurs; migrant entrepreneurs are united by a set of socio cultural connections and regular patterns of interaction among people sharing a common national background or migration experiences (Waldinger et al, 1990); iii) Minority entrepreneurs; minority entrepreneurs are business owners who are not of the majority population (US Department of Commerce, 1997).

The literature mentions both culture and the disadvantage context in explaining why migrants become self-employed (Johnson, 2000). Some migrants left their own country in the first place to start their own business in the host country, because they had no opportunity to 
do this in their own country (Choenni, 1997). This phenomenon stimulates the growth of selfemployment drastically (Rath, 1998). According to Lee et al., (1997) there is a 'social resources explanation'; the success of migrant minority businesses can in part be explained by the existence of such social resources as rotating credits, a protected market and a labour source. Another explanation and argument that migrant minorities are more likely to become entrepreneurs in comparison with native people can be related to the margination theory, stating the importance of an (negative) event, triggering the start-up of new firms (Verheul et al., 2001). According to this theory, the creation of an enterprise is not always the result of a deliberate and intentional act or a result of rational decision making. For most people, starting a business begins with the shattering of a previous life pattern. After this general overview of the concept of migrant entrepreneurship, we will investigate now migrant entrepreneurship from socio-economic perspective, including the main characteristics of migrant entrepreneurs, their motivation and performance.

\subsection{Migrant entrepreneurship from a socio-economic perspective}

Within the literature migrant entrepreneurs are characterized by certain general features. These features of course do not apply to all migrant entrepreneurs; it is merely an indication of what the migrant entrepreneur is, and in what way they do differ from the regular entrepreneur. For individuals or people who are unable to adapt to a social system, such as migrant and migrant minority groups, their marginal social position is a driving force to become self-employed. Self-employment in this case is not only a means of earning a living; it is also a way of recognition and social acceptance (Veciana, 1999). Motivation is an important aspect of any form of entrepreneurship, but especially in migrant entrepreneurship (Masurel et al., 2005). Cantillon and Marx emphasised that profit may motivate people towards business entry and self-employment. The desire to take risk and a spirit of adventure may be another motive (Knight, 1921). Some have greater access to information or knowledge and wish to exploit that advantage (Kirzner, 1973). The entrepreneur may be driven not only by economic motives but also by psychological motives like the desire to innovate and create new products (Schumpeter, 1934).

There is also a negative and a positive view in motivation of migrant entrepreneurship. Within the negative view migrant entrepreneurship exists because of forcefully reasons, such as high unemployment rates and discrimination. Kloosterman (1998) stressed the fact that high levels of unemployment provide the motivation for migrants to become entrepreneurs. In countries with a high unemployment rate among natives, migrants are pushed out of the labour market and become entrepreneurs (Tubergen, 2004). It is argued that migrants opt for self-employment in order to avoid racial discrimination in the host country's labour market, which forces them to accept low-paid jobs and blocks upward 
mobility (Ram, 1994). Some individuals may even have no other option but to choose selfemployment. This is frequently advanced in the context of migrant entrepreneurship.

Recently, attention has been paid to monitoring the social and economic position of minorities. The latter has been found to be weak as compared to the native people. Migrant workers have a lower level of education, and their children exhibit higher dropout rates (Tesser, 1999). They often occupy unskilled and simple or very simple jobs (Veenman, 1999). Their unemployment rates are higher and their average incomes are lower in comparison with the native workers (Kee, 1993; Rettab, 1995). The level of education of these new entrants is a variable for which contrasting results have been obtained. The results vary on the existence of a significant impact and nature of this impact. Among the studies finding that education has a significant impact, the nature of impact varies from study to study. Some find a positive relation, while others find a negative one. Cooper et al., (1987) and Robinson and Sexton (1994) shows that the self-employment decision is influenced by educational attainment. However, a study at the macro level by Uhlaner and Thurik (2004) shows that a higher level of education in a country is accompanied by a lower self-employment rate. Wit and van Winden (1989) reports that education is positively correlated with self-employment in the US, but negatively in the EU.

Migrant minorities consist of two types of migrants. One is the first-generation group, consisting of traditional migrants who were directly recruited for employment reasons. This group is less educated, with most education being achieved in the country of origin. The second group is the second generation, consisting of young dependants born in the host countries, where their entire education has been attained. This group masters the language of the host country better than the first generation does, and is relatively more qualified and acquainted with the local labour market. Not surprisingly, this group is generally found to be more ambitious and selective in choosing a job.

Mostly first generation migrant entrepreneurs undertake their own business impulsively without first deciding a good-stock taking market. As a consequence of this start they serve the same customers-group with the same products and service as their competitors without any distinguishing. This leads to enormous prize competition, a falling behind in entrepreneur's income and a high fall out percentage amongst young migrant businesses. Masurel et al., (2003) distinguish some general features that are typically applicable to migrant entrepreneurs, like informal and formal networks, clients, business financing, workforce and geographic clustering. In cases of information gathering or help in certain situations migrant make use of their own migrant groups. This is also referred to as the 'own group'. Usually, migrant entrepreneurs find a niche in their migrant community and start up in an ethically well-defined market, so as to provide typical services and products. An enclave economy can then positively affect the perspective of migrant entrepreneurs. Migrant groups 
that produce a strong entrepreneurial group can be of great economic significance for the migrant business community as well as for the total community, through job and opportunity creation (Rettab, 2001). Besides co-migrant clients, the migrant entrepreneur is also close to his own migrant group when it comes to the work force, or business financing. The social networks offer a flexible and efficient opportunity to recruit employees. Migrant entrepreneurs prefer hiring and supporting other migrants in their economic ventures as they enjoy privileged access to the migrant labour and can frequently employ paternalistic arrangements to extract more labour, as well as pay lower wages (Razin, 1989). Migrant entrepreneurs can satisfy special needs of co-migrant clients, since both share the same language, culture and religion and therefore communicate better. The migrant entrepreneur can also acquire financial capital and loan production resources from the informal networks. While native entrepreneur usually loan their starting capital from the bank, migrant entrepreneurs are less likely to receive bank funding than native entrepreneurs are (Rath, 2000), and therefore often lend capital from family or other group members.

Migrant entrepreneurs usually join up less with native formal networks, like retailer groups, trade associations and franchise organizations. Foreign activities are usually concentrated in certain geographic clusters. Especially in the bigger cities we can find this geographical concentration, because migrants start their businesses in places where already a large population of people live with the same migrant background. Foreign activities are usually concentrated in certain geographic clusters, since migrants start their businesses in places where already a large population of people live with the same migrant background.

If migrant businesses remain limited to the migrant market, their potential for growth is sharply circumscribed (Aldrich et al., 1990). The obstacle to growth is the migrant market itself, which can support only a restricted number of businesses, because it is quantitatively small and because the migrant population is often too impoverished to generate sufficient buying power to fuel growth (Aldrich et al., 1990). Rath (2000) emphasized that the opportunities and strategies of entrepreneurs are closely linked to their embeddedness in the economic, political-institutional, and social environments; these external factors, such as social embeddedness, also have a great influence on the start and development of migrant businesses. It is important to identify the causes and backgrounds of differences in performance of these groups, seen against the background of mainly American experiences. Are migrant entrepreneurs a "sign of hope" for social cohesion problems in the city? Migrant groups that produce a strong entrepreneurial group can be of great economic significance for the migrant business community as well as for the total community, through job and opportunity creation (Rettab, 2001). Van Delft et al (2000) revealed that migrant-related social networks may provide several advantages: they appear to be multifaceted and flexible, and offer good possibilities for the efficient recruitment of personnel and capital. The major 
advantage of migrant entrepreneurship may however be the fact that it may contribute to resolving the problematic employment situation of young people in migrant segments of the urban economy (Masurel et al. 2005).

\subsection{Migrant entrepreneurship from a cultural diversity perspective}

Culture can be described as the values, norms and attitudes in a group (Verheul et al., 2001). As mentioned before, cultural diversity is the variety of human cultures in a specific region, or in the world as a whole (Wikipedia). The phenomenon of cultural diversity has been extensively investigated by Hofstede (1991, 2001). He interprets culture as a collective and interactive set of common identity values that are decisive for a group response (or behaviour) vis-à-vis its external environment. Cultural differences are the result of national, regional, migrant, social class, religious, gender, and language variations. Culture manifests itself in different appearances in relation to geographic location, physical environment, nation, history, socio-economic traditions and conditions, political systems, religious circumstances, common language or dialect, technologies and work modes, or education and deeds. Clearly, culture is not always an unambiguous concept and may often be fuzzy in nature. Consequently, cross-cultural research is often based on qualitative characteristics of the target group and not so easy to quantify. The great merit of the work of Hofstede is that he has managed to design quantifiable indicators for cross-cultural comparison. His research has prompted an avalanche of interesting research on cultural diversity, with a particular view to the development of cross-cultural comparative studies in industrial organizations and management practices. Interesting follow-up of his work can be found inter alia in Trompenaars (1994), Milberg et al. (1995), Verbeke (2000), Ardichvili et al. (2002), Christie et al. (2003), Shulruf et al. (2003), McSweeney (2002), Ronald et al. (2004), Stephen et al. (2004) and Bergeron et al. (2005). The economic benefits of cultural diversity in the city may be manifold, as this may enrich the socio-economic opportunity base, create a varied supply of talents on the labour market, or enhance the creativity possibilities in the city (Jacobs, 1961; Florida, 2002). In the context of migrant entrepreneurship, several scholars have highlighted the impact of different migrant group cultures on entrepreneurship. The international literature on entrepreneurship and innovation pays much attention to the importance of cultural diversity in business behaviour.

In the recent literature on cultural diversity we can observe two major strands (see for an interesting overview Vermeij 2006), viz. the assimilation perspective and the identity perspective. The assimilation perspective takes for granted that interaction between different cultural or migrant groups may ultimately eliminate cultural boundaries (see Alba et al., 1997). The identity perspective on the other hand assumes that belonging to a migrant culture may have an indigenous meaning, as it creates a support system based on group identity (see 
Nagel 2002). Three environmental factors may be distinguished that impact on someone's migrant positioning: economic or socio-cultural competitive conditions (e.g., labour market, life style) (see e.g. Olzak 1992), resource mobilization (e.g. due to the strength or size of a specific population group) (see e.g. Moghaddam et al., 1992) or social identity (on the basis of e.g. positive role models, high self-esteem or a high social status of some group members) (see e.g. Austin et al., 1979).

The assimilation-identity dilemma is not only - and perhaps not predominantly determined by socio-cultural and migrant factors, but also - and perhaps mainly - by the economic context of migrants. In many cases, it turns out to be difficult for migrant groups to enter the regular labour market due to language deficiencies, low skills, lack of network relations etc. This may easily create a dual labour market system, in which migrant groups are condemned to the lowest segment as a result of filtering-down phenomena. This will not stimulate assimilation. Those who feel the drive to climb higher up the socio-economic ladder may then be forced to become self-employed and start their own business as a migrant entrepreneur, especially in those cases where the migrant market has a sufficiently large critical mass (cf. Halter, 2000). This may be another from of lack of assimilation (or group identity formation), although an expanding migrant business may again lead to more assimilation after a break-out strategy.

In conclusion, cultural diversity is an essential component of the study of migrant entrepreneurship. Differences in culture - interpreted in a broad sense - may prompt different types of economic behaviour and entrepreneurship. The driving forces and the conditional framework of cultural diversity call for further empirical work. In the sequel we will illustrate a few of the above mentioned arguments by a reference to some facts in the Netherlands.

\section{MIGRANT ENTREPRENEURSHIP IN THE NETHERLANDS}

In the 1960s, the Netherlands mainly recruited low-skilled workers from Spain, Italy and Greece, while later on guest-workers were acquired from Turkey and Morocco. Before the arrival of the first-generation migrants from Turkey, Morocco, Italy and Spain, the indigenous working population in the Netherlands had largely quit working in the industries. Therefore the arrival of these migrant groups was required to meet the need for low-skilled workers in the industrial sector. From 1956 till 1963 different industries also recruited workers from Surinam, but this recruitment stopped because of negative experiences with this group (Rath, 1998). Also large inflows of people from the Dutch Antilles could be observed. The sixties were remarkable for the large-scale labour migration from countries from around the Mediterranean. At the beginning of the seventies people thought the bigger part of the foreign workers should stay in the Netherlands only temporary, but after a couple years it became clear that many migrants would settle here definitely. And finally, due to war conditions in various parts of the world in the past decade - both inside and outside Europe - 
asylum seekers and refugees entered the Dutch society, e.g. from Yugoslavia, Somalia, Afghanistan and Iran.

The Netherlands has shown a remarkable openness vis-à-vis foreigners, a situation that can clearly be observed in the history of Amsterdam. At present, the share of migrants in Dutch society is approx. 20 percent, while the share of non-western migrants is about 10 percent (CBS 2003, 2004). From the non-western migrant population, three groups have a dominant position (namely approx. 60 percent), viz. Turks, Moroccans and Surinamese. It is noteworthy that migrant entrepreneurship is typically occurring in the city. Amsterdam, for instance, has a rich variety of migrant entrepreneurs. For a long time Amsterdam was the place of settlement for major migrant groups of different national and cultural origin. Jewish people were a driving force, but not the only entrepreneurial group in the city (Lucassen et al., 1994); other examples of early entrepreneurial groups were Belgian manufacturers of straw heads, German bakeries and breweries, and Italian plaster sculpture sellers (Henkes, 1995; Miellet, 1987; Schrover, 1996).

The rich history of the city of Amsterdam has clearly demonstrated that a large influx of dedicated and professional migrants from several countries has generated new production modes and innovations, which have contributed significantly to the wealth and international position of the city. According to Hessels et al. (2005) more highly educated people form a majority of those involved in early-stage entrepreneurial activity in the Netherlands. They also have a more positive perception of setting up their own firm compared to people with a more limited education and are comparatively often active in business services and consumeroriented sectors. If their skill levels are below average Dutch standards, they may most likely be found in lower segments of the labour market (Borjas, 1995). In general, their wages turn out to be lower than the Dutch average (de Graaff, 2002), but there is also a great variation in wage levels among different migrant groups.

The tendency or ability to become self-employed differs also between native people and migrants; immigration involves taking risks and this is also the case for entrepreneurship. Migrants are therefore considered to have an appropriate attitude or set of mind to start a business (Verheul et al, 2001). Jansen et al., (2003) concluded that, despite certain disadvantages compared with the native Dutch population, migrants from Turkey show the same rate of entrepreneurship. This group is definitely not afraid of taking any risks. In their eyes if it works out well, it is great. If not, it is just seen as a misfortune and they are helped and supported by family and friends to set up a new business when they go bankrupt. The Dutch are careful when compared with the Turks as they think ten times before starting off. The Turkish entrepreneurs on the other hand do believe in their motto 'Pratik zeka' which stands for 'practical mind'. The next section will compare and evaluate in a more detailed 
way the entrepreneurial behaviour of different migrant groups in the Netherlands in order to highlight the socio-economic and cultural differences among them.

\subsection{Socio-economic and cultural diversity in migrant entrepreneurship: evidence}

\section{from the Netherlands}

In order to evaluate migrant entrepreneurship from the perspective of cultural diversity, in this section we address different migrant group entrepreneurs in the Netherlands, we compare the socio-economic and cultural differences between these migrant groups, therefore we aim to highlight the cultural diversity in migrant entrepreneurship. We focus mainly on four active and dominant migrant groups viz. Turks, Moroccans, Surinamese, and Antilleans in the Netherlands and we compare these groups with each other as well as with native Dutch group in terms of their entrepreneurial behaviour and performance. Our comparison and evaluation are, of course, limited with the available data.

Since 1970, the number of migrants in the Netherlands has shown a rapid increase. Most migrants into the Netherlands originate from non-western countries (Jansen et al., 2003), from Turkey, Morocco, Surinam and the Antilles. Table 1 illustrates in absolute figures the number of migrant individuals living in the Netherlands. We can see that the Turkish migrant group is the biggest group among the four migrant groups. The population increased each year for each group.

Table- 1: $\quad$ Important migrant minorities and natives in the Netherlands (2000-2006) in absolute figures (x1000). Source: (CBS, 2006).

\begin{tabular}{|l|l|l|l|l|l|l|}
\hline \multirow{2}{*}{ Year } & Turks & Moroccans & Surinamese & Antilleans & Dutch \\
\hline \multirow{4}{*}{$\begin{array}{c}\text { Total } \\
\text { popu- } \\
\text { lation }\end{array}$} & 2000 & 308.9 & 262.2 & 302.5 & 107.2 & 13088.6 \\
\cline { 2 - 7 } & 2001 & 319.6 & 272.2 & 308.8 & 117.1 & 13116.9 \\
\cline { 2 - 7 } & 2002 & 330.7 & 284.1 & 315.2 & 124.9 & 13140.3 \\
\cline { 2 - 7 } & 2003 & 341.4 & 295.3 & 320.7 & 129.3 & 13153.8 \\
\cline { 2 - 7 } & 2005 & 351.7 & 306.2 & 325.3 & 130.7 & 13169.9 \\
\cline { 2 - 7 } & 2006 & 364.6 & 315.8 & 329.4 & 130.5 & 13182.9 \\
\hline
\end{tabular}

The migrant population from Turkey and Morocco in the Netherlands are very similar regarding their demographical composition. They are on average least well educated, most often married, and most migrant from these countries consider themselves to be Muslim. The migrants from Surinam and Antilles are better educated, more familiar with the Dutch culture and language, and more often single or single parents. All migrant populations have in common that they are relatively young as compared to the native Dutch population (Jansen et al., 2003). Migrants from Surinam and the Antilles also have similar demographical characteristics. Their age distribution is similar to the age distribution of migrant from Turkey and Morocco. Regarding the labour force participation rate of women and the share of 
married couples in the total number of households, they have much in common with the native Dutch population. In the second table we can also see that the educational level is lowest for migrant groups from Turkey and Morocco. Migrants from Surinam and the Antilles have on average higher educational levels, yet not as high as those of the native population.

The above mentioned migrants often find themselves in marginal economic positions. Entrepreneurship can be a way to improve the economic position of migrants (Choenni, 1997). The rate of entrepreneurship shows a considerable variation over time and between countries. This is especially true for populations of migrants. This is also the case for the Netherlands. More and more, entrepreneurship is recognized as an important source of job growth and economic development in the Netherlands (Van Stel et al., 2002). The last years, numbers of entrepreneurship have increased among people of different migrant minority groups in the Netherlands. One out of five newly set up businesses in the Netherlands is undertaken by a migrant entrepreneur. This group is mostly working in the service sector and delivers high-quality products. This group takes risks much easier, since they are stimulated by their parents. In Table 2 we can also see that their rate of first and second generation entrepreneurs has risen steadily during the last decade.

Table- 2: Distribution of main migrant entrepreneurs in the Netherlands (1999-2003) in absolute (x1000) and relative figures. Source: (CBS, 2006).

\begin{tabular}{|c|c|c|c|c|c|c|c|c|c|c|c|c|c|}
\hline \multirow{2}{*}{\multicolumn{2}{|c|}{ Year }} & \multicolumn{3}{|c|}{ Turks } & \multicolumn{3}{|c|}{ Moroccans } & \multicolumn{3}{|c|}{ Surinamese } & \multicolumn{3}{|c|}{ Antilleans } \\
\hline & & $\mathrm{t}$ & $\mathrm{m}$ & $\mathrm{f}$ & $\mathrm{t}$ & $\mathrm{m}$ & $\mathrm{f}$ & $\mathrm{t}$ & $\mathrm{m}$ & $\mathrm{f}$ & $\mathrm{t}$ & $\mathrm{m}$ & $\mathrm{f}$ \\
\hline \multirow{10}{*}{$\begin{array}{l}\text { first } \\
\text { generation } \\
\text { entrepre- } \\
\text { neurs }\end{array}$} & '99 & 7.2 & 5.9 & 1.3 & 2.5 & 2.2 & 0.3 & 5.1 & 3.5 & 1.6 & 1.1 & 0.7 & 0.4 \\
\hline & $\%$ & 91 & 92 & 87 & 89 & 92 & 75 & 80 & 80 & 80 & 70 & 70 & 80 \\
\hline & '00 & 8.2 & 6.8 & 1.4 & 3.0 & 2.6 & 0.4 & 5.6 & 3.9 & 1.7 & 1.2 & 0.8 & 0.4 \\
\hline & $\%$ & 88 & 89 & 82 & 88 & 90 & 80 & 79 & 80 & 77 & 67 & 67 & 67 \\
\hline & '01 & 9.6 & 8.0 & 1.6 & 3.5 & 3.1 & 0.4 & 6.2 & 4.4 & 1.8 & 1.4 & 1.0 & 0.4 \\
\hline & $\%$ & 87 & 88 & 84 & 88 & 89 & 80 & 79 & 81 & 75 & 71 & 71 & 67 \\
\hline & '02 & 9.9 & 8.3 & 1.6 & 3.7 & 3.3 & 0.4 & 6.2 & 4.3 & 1.9 & 1.4 & 0.9 & 0.5 \\
\hline & $\%$ & 86 & 87 & 84 & 88 & 89 & 80 & 78 & 78 & 76 & 64 & 64 & 67 \\
\hline & '03 & 10.2 & 8.6 & 1.6 & 3.9 & 3.4 & 0.5 & 6.3 & 4.3 & 2.0 & 1.5 & 1.0 & 0.5 \\
\hline & $\%$ & 86 & 87 & 80 & 89 & 89 & 83 & 79 & 78 & 80 & 71 & 71 & 71 \\
\hline \multirow{10}{*}{$\begin{array}{l}\text { Second } \\
\text { generation } \\
\text { entrepre- } \\
\text { neurs }\end{array}$} & '99 & 0.8 & 0.6 & 0.2 & 0.3 & 0.2 & 0.1 & 1.2 & 0.8 & 0.4 & 0.5 & 0.3 & 0.2 \\
\hline & $\%$ & 10 & 9 & 13 & 11 & 8 & 25 & 19 & 19 & 20 & 33 & 30 & 40 \\
\hline & '00 & 1.0 & 0.8 & 0.2 & 0.4 & 0.3 & 0.1 & 1.4 & 0.9 & 0.5 & 0.6 & 0.4 & 0.2 \\
\hline & $\%$ & 11 & 11 & 12 & 12 & 10 & 20 & 20 & 19 & 23 & 33 & 33 & 33 \\
\hline & '01 & 1.3 & 1.0 & 0.3 & 0.4 & 0.3 & 0.1 & 1.6 & 1.1 & 0.5 & 0.6 & 0.4 & 0.2 \\
\hline & $\%$ & 12 & 11 & 16 & 10 & 9 & 20 & 21 & 20 & 21 & 30 & 29 & 33 \\
\hline & '02 & 1.5 & 1.2 & 0.3 & 0.5 & 0.4 & 0.1 & 1.8 & 1.2 & 0.6 & 0.7 & 0.5 & 0.2 \\
\hline & $\%$ & 13 & 13 & 16 & 12 & 11 & 20 & 22 & 22 & 24 & 33 & 36 & 29 \\
\hline & '03 & 1.7 & 1.3 & 0.4 & 0.5 & 0.4 & 0.1 & 1.8 & 1.2 & 0.6 & 0.7 & 0.5 & 0.2 \\
\hline & $\%$ & 14 & 13 & 20 & 11 & 11 & 17 & 23 & 22 & 24 & 33 & 35 & 29 \\
\hline \multirow{5}{*}{$\begin{array}{l}\text { Total } \\
\text { of entrepre- } \\
\text { neurs }\end{array}$} & '99 & 7.9 & 6.4 & 1.5 & 2.8 & 2.4 & 0.4 & 6.4 & 4.4 & 2.0 & 1.5 & 1.0 & 0.5 \\
\hline & '00 & 9.3 & 7.6 & 1.7 & 3.4 & 2.9 & 0.5 & 7.1 & 4.9 & 2.2 & 1.8 & 1.2 & 0.6 \\
\hline & '01 & 11.0 & 9.1 & 1.9 & 4.0 & 3.5 & 0.5 & 7.8 & 5.4 & 2.4 & 2.0 & 1.4 & 0.6 \\
\hline & '02 & 11.5 & 9.5 & 1.9 & 4.2 & 3.7 & 0.5 & 8.0 & 5.5 & 2.5 & 2.1 & 1.4 & 0.7 \\
\hline & '03 & 11.9 & 9.9 & 2.0 & 4.4 & 3.8 & 0.6 & 8.0 & 5.5 & 2.5 & 2.1 & 1.4 & 0.7 \\
\hline
\end{tabular}

Legend: Percentage mean: the share of migrant entrepreneurs of a generation cohort in the total of migrant entrepreneurs of the total population category concerned. 
From the figures in Table 2 we can conclude that first generation migrants are far more entrepreneurial than the second generation migrants. Among the Turkish and Moroccan migrant groups it can be seen that men are relatively more entrepreneurial. The other two major groups of migrants from Suriname and the Dutch Antilles show that entrepreneurship is more or less evenly distributed among male and female. When considering the second generation migrants from the Turkish and Moroccan groups it can be seen that male entrepreneurs are relatively more present than female entrepreneurs. With the Surinamese and Antillean groups it can be seen that second generation women are more entrepreneurial.

The net gender effect is very strong for the Surinamese population within the Netherlands. The labour force participation rate in general is relatively high for female migrants from Suriname. However, besides the relative high labour force participation rate, there is still a relative low entrepreneurship rate for female Surinamese migrants when compared to the native female Dutch population. On the other hand, the entrepreneurship rates for female Surinamese are still somewhat higher than entrepreneurship rates for female Turkish and Moroccan migrants. Female migrants from Turkey and Morocco are far less entrepreneurial than for instance the native Dutch females. This is probably related to cultural and/or religious differences. Besides entrepreneurship rates, labour force participation rates are also much lower than of native Dutch women. The combination of high labour force participation rate and a low rate of entrepreneurship for female Surinamese migrants may be related to the relatively high share of single parent families for this migrant group (assuming that most of the single parents are women). Antilleans and Surinamese seem very successful in Table 3 and the second generation entrepreneurs in these groups have almost the same rate of profit with the first generation. When we looked at the migrants from Turkey and Morocco, the profit of the first generation entrepreneurs is much higher than the second generation. Although the Surinamese and Antillean group are much smaller than the other two groups, they have a higher profit. This may be caused by differences in their entrepreneurial behaviour. 
Table -3: $\quad$ Profit of migrant entrepreneurs in the Netherlands (1999-2003) in absolute figures (x1000). Source: (CBS, 2006).

\begin{tabular}{|c|c|c|c|c|c|}
\hline & Year & Turks $(€)$ & Moroccans (€) & Surinamese $(€)$ & Antilleans $(€)$ \\
\hline \multirow{5}{*}{$\begin{array}{l}\text { Profit of } \\
\text { first generation } \\
\text { entrepreneurs }\end{array}$} & '99 & 18.0 & 15.5 & 19.2 & 22.0 \\
\hline & '00 & 21.0 & 19.4 & 21.4 & 22.3 \\
\hline & '01 & 19.3 & 17.2 & 21.4 & 21.8 \\
\hline & '02 & 19.2 & 18.0 & 22.9 & 24.1 \\
\hline & '03 & 18.0 & 17.0 & 21.9 & 23.1 \\
\hline \multirow{5}{*}{$\begin{array}{l}\text { Profit of } \\
\text { second generation } \\
\text { entrepreneurs }\end{array}$} & '99 & 13.9 & 12.2 & 21.2 & 18.8 \\
\hline & ${ }^{\prime} 00$ & 14.9 & 15.7 & 23.0 & 19.4 \\
\hline & '01 & 14.0 & 12.7 & 20.9 & 19.7 \\
\hline & '02 & 13.8 & 15.2 & 22.2 & 22.2 \\
\hline & '03 & 12.8 & 12.6 & 20.7 & 22.1 \\
\hline \multirow{5}{*}{$\begin{array}{l}\text { Profit of total } \\
\text { entrepreneurs }\end{array}$} & '99 & 17.6 & 15.2 & 19.6 & 21.0 \\
\hline & '00 & 20.3 & 19 & 21.7 & 21.3 \\
\hline & '01 & 18.7 & 16.7 & 21.3 & 21.1 \\
\hline & '02 & 18.5 & 17.6 & 22.7 & 23.4 \\
\hline & '03 & 17.2 & 16.4 & 21.6 & 22.7 \\
\hline
\end{tabular}

\section{RETROSPECT AND PROSPECT}

With the advent of the era of mass migration in Europe, the issue of cultural diversity has gained increasingly societal and political interest, unfortunately often from a negative perspective. It has even become a source of big concern in European societies. Modern societies in the western world are increasingly faced with cultural diversity as a result of international migration. Diversity is increasingly valued and its social, cultural and economic benefits are recognized. Modern cities mirror the openness of an industrialized global society, as they have become a meeting place of people from different national, cultural and migrant origin. For example, an open city like Amsterdam will soon have a majority of people from a different migrant origin than the indigenous Dutch population.

In order to evaluate migrant entrepreneurship from the perspective of cultural diversity, in this section we addressed different migrant group entrepreneurs in the Netherlands, we compared the socio-economic and cultural differences between these migrant groups. We focused mainly on four active and dominant migrant groups viz. Turks, Moroccans, Surinamese, and Antilleans in the Netherlands and we compared these groups with each other as well as with native Dutch group in terms of their entrepreneurial behaviour and performance. The migrant population from Turkey and Morocco in the Netherlands are very similar regarding their demographical composition. They are on average least well educated and most often married. The migrants from Surinam and Antilles are better educated, more familiar with the Dutch culture and language, and more often single or single parents. Migrants from Surinam and the Antilles also have similar demographical characteristics. Regarding the labour force participation rate of women and the share of married couples in the total number of households, they have much in common with the 
native Dutch population. The educational level is lowest for migrant groups from Turkey and Morocco. Migrants from Surinam and the Antilles have on average higher educational levels, yet not as high as those of the native population.

The above mentioned migrants often find themselves in marginal economic positions. Entrepreneurship can be a way to improve the economic position of migrants (Choenni, 1997). The last years, numbers of entrepreneurship have increased among people of different migrant minority groups in the Netherlands. We can conclude that first generation migrants are far more entrepreneurial than the second generation migrants. Among the Turkish and Moroccan migrant groups it can be seen that men are relatively more entrepreneurial. The other two major groups of migrants from Suriname and the Dutch Antilles show that entrepreneurship is more or less evenly distributed among male and female. When considering the second generation migrants from the Turkish and Moroccan groups it can be seen that male entrepreneurs are relatively more present than female entrepreneurs. With the Surinamese and Antillean groups it can be seen that second generation women are more entrepreneurial. Antilleans and Surinamese seem very successful and the second generation entrepreneurs in these groups have almost the same rate of profit with the first generation. When we looked at the migrants from Turkey and Morocco, the profit of the first generation entrepreneurs is much higher than the second generation. Although the Surinamese and Antillean group are much smaller than the other two groups, they have a higher profit. This may be caused by differences in their entrepreneurial behaviour.

All in all, migrant entrepreneurs deserve more attention. In order to succeed in the current business climate it is essential that businesses recognize that customers all over the world have choice and consumers have to be targeted for their business. Working with migrant minority businesses offers the opportunity to do just that. Migrant minorities are usually a highly motivated and qualified entrepreneurial group. Migrant minority businesses mostly fall into the category of Small and Medium-sized Enterprises (SMEs). Small and medium sized enterprises play a significant role in the domestic economies of most countries. Each and every successful self-employed migrant or minority business contributes to improved social and economic integration. A growing migrant economy creates a virtuous circle: business success gives rise to a distinctive motivational structure, breeding a community-wide orientation towards entrepreneurship.

Migrant entrepreneurs deserve also more attention, since this group not only has to deal with arbitrary problems of entrepreneurship, but also with specific problems that occur among these group members. Firstly, communication is an important aspect which needs attention. One of the main problems is the distance in approach and the loads of information send via letters and on internet. This type of communication is not effective among migrant entrepreneurs, since they would consider the personal approach. Secondly, the fact that most 
migrant entrepreneurs are uninformed and have a limited network is a main problem. Most of the time they are unaware of the issuing of the rules and the facilities which are provided. Rarely do they have a business plan which causes an unprepared start. Developing roll models would help in this case. Finally, the minimum contact between entrepreneurs and advice organizations such as business associations, Chambers of Commerce and native entrepreneurs is a problem as well. One important consequence is that migrant entrepreneurs do not make use of the information/ support/ assistance possibilities. It is striking, that this is a demanding need in this group. Motives of not making use of the facilities are unfamiliarity, communicational problems, and limited access to information. 


\section{REFERENCES}

Alba, R. and V. Nee (1997), "Rethinking Assimilation Theory for a New Era of Immigration", International Migration Review, 31, pp. 826-874.

Aldrich, H.E. and R. Waldinger (1990), "Migrantity and Entrepreneurship", Annual Review of Sociology,16, pp. 111-135.

Ardichvili A. and K.P. Kuchinke (2002), "Leadership Styles and Work-Related Values of Managers and Employees of Manufacturing Enterprises in Post-Communist Countries", Human Resource Development Quarterly, 12, pp. 363-383.

Austin, W.G. and S. Worchel (eds.) (1979), The Social Psychology of Intergroup Relations, Brooks/Cole, Monterey, Cal., pp. 33-47.

Basu, A. and E. Altinay (2002), “The Interaction Between Culture And Entrepreneurship In Londen's Immigrant Businesses”, International Small Business Journal, 20, pp. 371-393.

Baycan-Levent T., E. Masurel and P. Nijkamp (2003), "Diversity in Entrepreneurship: Migrant and Female Roles in Urban Economic Life”, International Journal of Social Economics, 30, pp. 1131-1161.

Berdowski, Z. (1994), Ouderen in Amsterdam 1993. Amsterdam: Koordinatie Kommissie Onderzoek van de Gemeente Amsterdam.

Bergeron N. and B.H. Schneider (2005), "Explaining Cross-National Differences in Peer-Directed Aggression: A Quantitative Synthesis", Aggressive Behavior, 31, pp. 116-137.

Borjas, G. (1995), "Migrantity, Neighbourhoods, and Human-Capital Externalities", American Economic Review, 85, pp. 365-90.

Bosma, N. (2002), Global Entrepreneurship Monitor 2002, Zoetermeer:EIM.

Butler, J.S. and P.G. Greene (1997), Migrant Entrepreneurship: The Continuous Rebirth of American Entrepreneurship, (in: D.L. Sexton and R.W. Smilor (eds.), Entrepreneurship 2000), Chicago, IL, Upstart Publishing, pp 267-289.

Carree, M.A. and A.R. Thurik (2003), The Impact of Entrepreneurship on Economic Growth. (In: Z.J. Acs and D.B. Audretsch (eds.), Handbook of Entrepreneurship Research), Kluwer, pp. 437-471.

CBS (Central Bureau of Statistics) (2003, 2004, 2006), Allochtonen in Nederland 2003, Voorburg.

Chaganti, R. and P.G. Greene (2000), "Who are Migrant Entrepreneurs? A Study of Entrepreneurs' Migrant Involvement and Business Characteristics”, Journal of Small Business Management, 40, pp. 126-143.

Cooper, A.C. and W.C. Dunkelberg (1987), "Entrepreneurial Research: Old Questions, New Answers And Methodological Issues”, American Journal of Small Businesses, 1, pp. 11-23.

Cormack, J. and J. Niessen (2002), "Supplier Diversity, The Case of Immigrant and Ethnic Minority Enterprises”,Background paper prepared for the Transatlantic Round Table on Supplier Diversity, Brussel.

Christie, P.M.J., I.W.G. Kwan, P.A. Stoebel and R. Baumhaut (2003), “A Cross-Cultural Comparison of Ethical Attitudes of Business Managers", Journal of Business Ethics, 46, pp. 263-287.

Cross, M. (ed.) (1992), Migrant Minorities and Industrial Change in Europe and North America, Cambridge University Press, Cambridge.

Van Delft, H. C. Gorter and P. Nijkamp (2000), “In search of migrant entrepreneurship

Opportunities in the city: A comparative policy study”, Environment and Planning C: Government and Policy, 18, pp. 429-451.

Esping-Andersen, G. (ed.) (1993), Changing Classes. Stratification and Mobility in Post-Industrial Societies, Sage, London.

Florida, R. (2002), The Rise of Creative Class, New York: Basic Books.

De Graaff, T. (2002), Migration, Migrant Minorities and Network Externalities, Thela Thesis, Amsterdam. Halter, M. (2000), Shopping For Identity, Schoiken, New York. 
Hébert, R. F. and A. N. Link, 1982, The Entrepreneur, New York: Praeger.

Henkes, B. (1995), Heimat in Holland, Duitse Dienstmeisjes, 1920-1950, Amsterdam; Babylon-De Geus.

Hessels, J., N. Bosma, and S. Wennekers, (2005), Nieuw Ondernemerschap in Herstel, Zoetermeer.

Hofstede, G. (1991), Cultures Organization, Software of the Mind; Intercultural Cooperation and ItsImportance for Survival. London: Mc Graw-Hill.

Hofstede, G. (2001), Culture's Consequences: Comparing Values, Behaviors, Institutions, and Organizations across Nations, Thousand Oaks, London, New Delhi: Sage Publications.

Jacobs, J. (1961), The Life and Death of Great American Cities, New York: Random House.

Jansen, M., J. de Kok, J. Spronsen, and S. Willemsen, (2003), Immigrant Entrepreneurship in the Netherlands Demographic Determinants of Entrepreneurship of Immigrants from Non-Western Countries'- Scales, Zoetermeer.

Johnson, P.J. (2000), "Migrant Differences in Self-Employment among Southeast Asian Refugees in Canada". Journal of Small Business Management, 38, pp. 78-86.

Kee, P. (1993), The Economic Status of Male Immigrants in the Netherlands (diss.), University of Amsterdam.

Kirzner, I. M. (1973), Competition and Entrepreneurship. Chicago: University of Chicago Press.

Kloosterman, R. (1997), Face 2 Face. (In: M. Hajer en F. Halsema (red.). Land in zicht!) Amsterdam: Bert Bakker/WBS, pp.163-179.

Kloosterman, R. (1998), Immigrant Entrepreneurship and the Welfare State, (in: J. Rath (ed.), Immigrant Businesses on the Urban Economic Fringe. A Case for Interdisciplinary Analysis). Houndmills, Basingstoke, Hampshire: Macmillan Press.

Kloosterman, R., J. van der Leun, and J. Rath (1998), “Across the Border: Immigrants' Economic Opportunities, Social Capital and Informal Business Activities”, Journal of Migrant and Migration Studies, 4, pp. 249-268.

Knight, F. H. (1921), Risk, Uncertainty and Profit. New York: Houghton Miffin.

Lamont, M. and V. Molnár (2002), "The Study of Boundaries in The Social Sciences", Annual Review of Sociology, 28, pp. 167-195.

Larsen, P. (1995), "Hebben Nederlanders dan geen Cultuur? Een Beschouwing over Nederlands Onderzoek naar 'Etnisch Ondernemerschap", Migrantenstudies, 11, pp. 30-38.

Light, I. (1972), Migrant Enterprises in America, University of California Press, Berkeley.

Lee, Y., T. Cameroen, P. Schaeffer and C.G. Schmidt (1997), "Migrant Minority Small Business: A Comparative Analysis of Restaurants in Denver”, Urban Geography, 18, pp. 591-621.

Lucassen, L. and R. Penninx (1994), Nieuwkomers, Nakomelingen, Nederlanders. Immigranten in Nederland 1550-1993, MES-Reeks 1. Amsterdam: Het Spinhuis.

Massey, D.S. and N.A. Denton (1993), American Apartheid: Segregation and the Making of the Underclass, Harvard University Press, Cambridge, MA.

Masurel, E., P. Nijkamp, M. Tastan and G. Vindigni (2002), "Motivations and Performance Conditions For Migrant Entrepreneurship”, Growth \& Change, 33, pp. 238-260.

Masurel, E. and P. Nijkamp (2003), Allochtoon Ondernemerschap, (in: P. Risseeuw and R. Thurik,Handboek Ondernemers en Adviseurs; Management en Economie van het Midden- en Klein Bedrijf), Kluwer, ch11.

Masurel, E. and P. Nijkamp (2005), Migrant Minority Entrepreneurs and Their Lack of InstitutionalCollaboration Reasons and Perceptions in the Franchise Sector, Tinbergen Institute, Amsterdam.

McSweeney, B. (2002), "Hofstede's Model of National Cultural Differences and their Consequences: A Triumph of Faith - A Failure of Analysis", Human Relations, 55, pp. 89-118.

Miellet, R.L. (1987), "Immigratie van Katholieke Westfalers en de Modernisering van de Nederlandse Detailhandel”, Tijdschrift voor Geschiedenis, 100, pp. 374-393. 
Milberg, S.J., S.J. Burke, H.J. Smith and E.A. Kallman (1995), "Values, Personal Information, Privacy and Regulatory Approaches", Communications of the ACM, 38, pp. 65-74.

Moghaddam, F.M. and S. Perrault (1992), "Individual and Collective Mobility Strategies among Minority Group Members", Journal of Social Psychology, 132, pp. 343-358.

Nagel, C. (2002), “Constructing Difference and Sameness”, Migrant and Racial Studies, 25, pp. 258-287.

Olzak, S. (1992), The Dynamics of Migrant Competition and Conflict, Stanford University Press, Stanford.

Van Praag, C.M. (1996), Determinants of Successful Entrepreneurship. Amsterdam: Thesis Publishers.

Ram, M. (1994), Managing to Survive: Working Lives in Small Firms, Oxford: Blackwell.

Rath, J. (1998), Een Etnische Stoelendans in Mokum. Over de Economische Incorporatie van Immigranten en hun Nakomelingen in Amsterdam, pp. 235-249, (in: A. Gevers (ed.), Uit de Zevende. 50 Jaar Sociaal-Culturele Wetenschappen aan de Universiteit van Amsterdam,. Amsterdam: Het Spinhuis, 1998.

Rath, J. (2000), Introduction; Immigrant Business and the Economic, Politico-Institutional and Social Environment, (in: J. Rath (ed.), Immigrant Business: The Economic, Political and Social Environment), London: Macmillan Press, pp1-19.

Razin, E. (1989), "Relating Theories of Entrepreneurship Among Ethnic Groups and Entrepreneurship in Space - The Case of the Jewish Population in Israel”, Geografiska Annaler, 71, pp. 167-181.

Razin, E. (1993), "Immigrant Entrepreneurs in Israel, Canada and California, Immigration and Entrepreneurship, Culture, Capital, and Migrant Networks", (in: I. Light and P. Bhachu (eds.), Transaction Publishers), New Brunswick, pp. 111-132.

Rettab, B. (2001), The Emergence of Migrant Entrepreneurship - A Conceptual Framework,EIM/Business and Policy Research, Zoetermeer.

Rettab, B. (1995), Economic Performance of the Immigrant Workforce: Case Study of the Netherlands,EUR Proefschrift.

Sahin, M., M. Rietdijk and P. Nijkamp (2006), “Ethnic Employees' Behaviour Vis-a-Vis Customers in the Service Sector", Research Memorandum, 2006-2.

Schrover, M. (1996), Omlopers in de Keulse potten en pottentrienen uit het Westerwald, pp. 101-120, (in: M. 't Hart, J. Lucassen and H. Schmal (eds.), Nieuwe Nederlanders. Vestiging van Migranten door de Eeuwen Heen), Amsterdam: Stichting Beheer IISG en SISWO/Instituut voor Maatschappijwetenschappen.

Schumpeter, J. A. (1934), The Theory of Economic Development. Translated by R. Opie from the second German edition [1926]. Cambridge: Harvard University Press.

Shulruf, B., J. Hattie and R. Dixon (2003), "Development of a New Measurement Tool for Individualism and Collectivism", paper presented at the NZARE/AARE Joint Conference 2003, Auckland, New Zealand.

Simon, G. (1993), Immigrant Entrepreneurs in France, pp. 125-139, (in: I. Light and P. Bhachu, Immigration and Entrepreneurship. Culture, Capital and Migrant Networks), London: Transaction Publishers.

Stephen W.L., J.C. Crotts, and F.L. Hefner (2004), "Cross-Cultural Tourist Behaviour: a Replication and Extension Involving Hofstede's Uncertainty Avoidance Dimension”, International Journal of Tourism Research, 6, pp. 29-37.

Stiglitz, J.E. and J. Driffill (2000), Economics, New York: W.W. Norton \& Company.

Super, I. (2005), Country of Origin as a Source of Opportunity, Master Thesis, RSM Erasmus University, Rotterdam.

Tuna, G. (2006), Ethnic Entrepreneurship: A Research in Entrepreneurial Attitude between People Originally From Turkey and Morocco, Master Thesis, Free University Amsterdam.

Thomas, A. S. and S.L. Mueller (2000), “A Case for Comparative Entrepreneurship: Assessing the Relevance of Culture", Journal of International Business Studies, 31, pp. 287-301. 
Tesser, P.T.M., J.G.F. Merens and C.S. van Praag (1999), Rapportage Minderheden 1999, Positie in het Onderwijs en op de Arbeidsmarkt, Sociaal en Cultureel Planbureau, The Hague.

Trompenaars, F. (1993), Riding the Waves of Culture: Understanding Cultural Diversity in Business, London: Nicholas Brealey.

Uhlaner, L. and A.R. Thurik (2004), "Post-materialism: A Cultural Factor Influencing Total Entrepreneurial Activity across Nations", Papers on Entrepreneurship, Growth and Public Policy no 70-2004. Max Planck Institute of Economics, Jena, Germany.

Van Stel, A., S. Wennekers, R. Thurik, P. Reynolds and G. de Wit (2003), "Explaining

Nascent Entrepreneurship Across Countries", Paper presented at the BKERC Conference, Babson College, 4-7 June 2003.

Van Tubergen F. (2004), The integration of immigrants in cross-national perspective, Wageningen: Ponsen \& Looijen b.v.

Veciana, J.M., (1999), "Entrepreneurship as a Scientific Research Programme”, Revista Europea de Dirrecion y Economia de la Empresa 8, pp. 2-10.

Veenman, J. (1999), Participatie en Perspectief, Verleden en Toekomst van Etnische Minderheden in Nederland, Lelystad: K.V. bv.

Verbeke, W. (2000), “A Revision of Hofstede et al.'s (1990) Organizational Practices Scale”, Journal of Organizational Behavior, 21, pp. 587-602.

Verheul, I., S. Wennekers, D. Audretsch and R. Thurik (2001), “An Eclectic Theory of

Entrepreneurship: Policies, Institutions and Culture”, Research Report 0012, EIM, Zoetermeer.

Vermeulen, H. and R. Penninx (eds.) (2002), Immigrant Integration, Het Spinhuis, Amsterdam.

Verweij, C. (2006), What is Cooking?, Ph.D Thesis, University, Utrecht.

Waldinger, R., Aldrich, H., Ward, R., \& Associates. (1990), Ethnic Entrepreneurs. London: Sage.

Waldinger, R.D., H.E. Aldrich, R. Ward and J. Blaschke (1990), Migrant Entrepreneurs; Immigrant Business in Industrial Societies, Sage Publications, Newbury Park, CA.

Waldinger, R. (1996), Still the Promised City? African-Americans and New Immigrants in Postindustrial New York. Cambridge, MA: Harvard University Press.

Ward, R. (1983), "Ethnic Communities and Ethnic Business: An Overview”, New Community, 11, pp. 1-9.

Werbner, P. (1990), "Renewing an Industrial Past: British Pakistani Entrepreneurship in

Manchester", Migration, 8, pp. 7-41.

Wennekers, S. and R. Thurik (1999), "Linking Entrepreneurship and Economic Growth", Small Business Economics 13, pp. 27-55.

De Wit, G. and F.A.A.M. van Winden (1989), "An Empirical Analysis of Self-Employment in the Netherlands", Small Business Economic, 1, pp. 263-272.

Wikipedia (2006), The Free Encylopedia. 